\title{
Feminilidade e lágrimas na literatura clássica, na Bíblia hebraica e na literatura rabínica
}

\author{
Femininity and tears in the classic literature, in the Hebrew Bible and in the \\ rabbinical literature
}

Daniela Susana Segre Guertzenstein *

\begin{abstract}
Resumo
A literatura dissemina crenças, mitos, valores culturais e ideologias que revelam conceitos de moralidade das épocas e dos ambientes em que foram produzidas. Esse artigo propõe investigar os personagens masculinos e femininos em diferentes literaturas para analisar a figura feminina e o choro maternal na Bíblia hebraica e na literatura rabínica (judaísmo). A literatura hebraica rabínica transmite tradições de práticas socializantes. Nesse contexto, entende-se a construção de arquétipos de gênero a partir da Bíblia hebraica e do universo literário hebraico rabínico do judaísmo ortodoxo. Determinam-se, assim, modelos sexistas específicos religiosos e seus padrões sociais. O objetivo deste artigo é apresentar versículos bíblicos hebraicos e a exegese rabínica dos textos que tratam do choro maternal. Revela-se que os homens são progenitores e as mulheres devem ser instintivamente maternas, porque ter filhos é o papel central feminino. A pesquisa incita a reflexão sobre a simbologia do choro maternal como padecimento sagrado, como um ato altruísta, que em várias religiões, doutrinas e culturas, transcendem a própria maternidade percebida como sacrifício.
\end{abstract}

Palavras-chave: choro; maternidade; Bíblia hebraica; literatura rabínica; Judaísmo.

\begin{abstract}
Literature discloses beliefs, cultural values, myths and ideologies which reveal concepts of morality of the environments when and where it was produced. This article proposes to investigate male and female characters in different literatures to analyze the female figure and the maternal cry in the Hebrew Bible and Rabbinic literature (Judaism). Rabbinical Hebrew literature teaches social practices through traditions. This context reveals the development of gender archetypes from the Hebrew Bible and in the rabbinical Hebrew literature universe of the Orthodox Judaism, which determines social patterns from religious specific sexist models. The purpose of this article is to expose the maternal cry in the Hebrew Bible and in the rabbinical exegesis; revealing that men are progenitors and women should be instinctively maternal, because having children is the central feminine role. The research carried out wants to prompt the reflection about the symbolism of the maternal crying as a sacred suffering, as an altruistic act, which in many religions, doctrines and cultures transcend the motherhood itself perceived as sacrifice.
\end{abstract}

Keywords: cry; maternity; Hebrew Bible; rabbinical literature; Judaism.

Artigo submetido em 07 de abril de 2019 e aprovado em 29 de abril de 2019.

* Doutora em Língua Hebraica, Literatura e Cultura Judaicas pelo DLO/FFLCH - USP. Professora da Faculdade de Filosofia, Letras e Ciências Humanas da USP. País de Origem: Brasil. E-mail: guertzenstein@uol.com.br 


\section{Introdução}

A supremacia da figura masculina sobre a feminina, na narrativa bíblica hebraica, revela a transmissão de valores chauvinistas, que fundamentam a exegese rabínica. Tais valores foram apropriados pelo cristianismo e incorporados à literatura clássica.

Desde a narrativa de Agamenon e Clitemnestra, na tragédia de Ésquilo, e na mitologia grega, a identidade masculina se sobrepunha à feminina, legitimando valores patriarcais, em detrimento do sistema matriarcal. A Rainha Clitemnestra, esposa de Agamenon, soube que os gregos haviam conquistado Tróia e estavam a caminho de casa. Agamenon cavalgava para casa junto com Cassandra, princesa troiana - agora escrava - com poderes de adivinhação. Ela previu que a morte chegaria à casa de Agamenon. Clitemnestra recebe Agamenon e Cassandra de braços abertos. Agamenon e Cassandra são assassinados. A rainha não se arrepende do ato cruel, porque acredita que Agamenon devia morrer por ter sacrificado a sua filha, Ifigênia (condição para a conquista de Tróia). Clitemnestra enterrou Agamenon e sua escrava juntos. ${ }^{1}$

Até esse ponto, é fácil identificar-se com Clitemnestra, uma mãe que está sofrendo pela morte de sua filha. Mas, quando Clitemnestra mata Cassandra, começa-se a duvidar do caráter de Clitemnestra. Na última cena da tragédia, encontra-se o amante de Clitemnestra, Egisto, que foi incitado planejar a morte de Agamenon com a sua amada.

A narrativa termina com um aviso para Egisto: que o filho de Agamenon vingará a morte de seu pai; como conexão com a peça subsequente da trilogia de Ésquilo, repleta de simbologias machistas que giram em torno de guerras e revanches chauvinistas.

\footnotetext{
${ }^{1}$ Agamémnon de Ésquilo (Elêusis, c. 525/524 antes da era comum - Gela, 456/455 antes da era comum) é o mais antigo dos poetas trágicos cujas obras chegaram até os nossos dias. Para Aristóteles, Esquilo foi o criador da tragédia. Ainda, de acordo com Aristóteles, Ésquilo (gr. Aiđđú̉oc) aumentou o número de personagens das peças para permitir conflitos entre eles; antes os personagens interagiam apenas com o coro.
} 
Na literatura religiosa do Corão, que fundamenta as tradições e leis islâmicas da Shari'a, lê-se que "a humanidade deve temer a seu Deus, que criou o homem de uma alma e criou dele a sua companheira e dispersou de ambos muitos homens e mulheres. E deve-se temer a Alá, o Deus do Corão, através de quem um pede ao outro, e aos úteros. E que, na verdade, Alá é sempre um Observador" (Corão 4:1) ${ }^{2}$. Esse versículo corânico fundamenta a doutrina religiosa machista segundo a qual as mulheres não têm alma. Segundo o Corão, a mulher deve ser submissa ao seu marido, que inclusive tem o direito de bater na sua mulher3 (Corão 4:34). Aliás, a mulher no islã não pode ser vista por homens e transitar pelo espaço público se não estiver envolta por véus (Corão 33:59) 4 .

A popularização de figuras de diferentes tradições, descontextualizadas, faz com que, no cristianismo, a imagem grega de Afrodite possa ser confundida com as ilustrações de Eva da Bíblia hebraica. Analisar os textos sobre identidades femininas e mulheres no universo literário de diferentes tradições colabora para que se entendam os valores sexistas que inspiram e fundamentam os padrões de inclusão (e exclusão) por gênero, em diferentes ambientes.

O judaísmo e o islã são fundamentalmente iconoclastas, restringindo a arte à criação de adornos. Já no cristianismo, pinturas que reproduzem corpos femininos e masculinos, ou formas angelicais, inspirados em imagens mitológicas gregas e bíblicas hebraicas, ornam paredes e tetos de capelas no Estado do Vaticano. Já as vestes abundantes de figuras de freiras e mulheres virtuosas, que ornam a maioria das instituições femininas católicas apostólicas romanas, são semelhantes às vestimentas das mulheres castas que cobriam o corpo e a cabeça e se dedicavam em

\footnotetext{
${ }^{2}$ Corão 4:1 - O mankind, fear your Lord, who created you from one soul and created from it its mate and dispersed from both of them many men and women. And fear Allah, through whom you ask one another, and the wombs. Indeed Allah is ever, over you, an Observer. (Tradução Sahih International)

${ }^{3}$ Corão 4:34 - Men are in charge of women by [right of] what Allah has given one over the other and what they spend [for maintenance] from their wealth. So righteous women are devoutly obedient, guarding in [the husband's] absence what Allah would have them guard. But those [wives] from whom you fear arrogance - [first] advise them; [then if they persist], forsake them in bed; and [finally], strike them. But if they obey you [once more], seek no means against them. Indeed, Allah is ever Exalted and Grand (Tradução Sahih International). Homens que abusam de mulheres não é uma exclusividade do islã. Contudo, o islã confere a permissão divina a esse crime civil que fere os direitos humanos, consagrando e legitimando esse ato de violência contra a mulher.

${ }^{4}$ Corão 33:59 - O Prophet, tell your wives and your daughters and the women of the believers to bring down over themselves [part] of their outer garments. That is more suitable that they will be known and not be abused. And ever is Allah Forgiving and Merciful (Tradução Sahih International).
} 
manter aceso o fogo de Vesta no templo de Juno5, a rainha dos deuses romanos, anterior ao cristianismo.

O antropólogo Pierre Bourdieu, ao analisar a identidade de gênero na literatura produzida em um determinado contexto cultural, repudia as pretensões absolutistas de padrões rígidos de objetividade. Ele derruba dogmas metodológicos de análises e interpretações, desenvolvendo uma consciência potencialmente libertadora, sem envolver o relativismo (BOURDIEU, 1992, p. 185). Segundo Bourdieu (2012), “a revolução do conhecimento, que na literatura se manifesta na popularização e reinterpretação contínua de diferentes textos, em contextos sociais diversos, tem consequências na concepção de estratégias destinadas a transformar a relação de forças material e simbólica entre os sexos no seio de todas as formas de dominação.

A investigação sobre sexualidade e inclusão feminina na sociedade é vastíssima. Assim como o universo evolui, os ambientes se desenvolvem, os corpos se transformam e as interações que determinam as propriedades que representam as diferentes identidades mudam. A miríade de sexualidades, já representadas na mitologia grega (dentre outras culturas), choca-se contra preconceitos de mitos sexistas binários de diferentes doutrinas e literaturas religiosas. Analisar a figura feminina e a idealização da maternidade no inconsciente coletivo perpassa o tema central deste artigo, que se atém em apresentar uma breve investigação sobre a identidade feminina e o choro maternal nos versículos bíblicos hebraicos e de textos da literatura rabínica que, continuamente reinterpretados, continuam a inspirar um número incalculável de pessoas há séculos.

Os versículos do Tanakh ${ }^{6}$ fundamentam valores prestigiados na literatura clássica ocidental, que continuam a reger organizações, principalmente religiosas, e a influenciar, com suas crenças, as perspectivas, percepções, interpretações e análises de pesquisas científicas, influenciando inclusive a produção intelectual

\footnotetext{
${ }^{5}$ Juno é a rainha dos deuses e esposa de Júpiter, na mitologia romana. Sua equivalente, na mitologia grega, é Hera. O mês de "junho" é uma homenagem à deusa Juno e era destinado à visitação do Templo de Juno em Roma.

${ }^{6}$ Tanakh: acróstico de Torá (em hebraico Ensinamento; livros do Pentateuco), Nevyim (Profetas) e Ketuvim (Escrituras).
} 
acadêmica. A pesquisa realizada apresenta o desenvolvimento do universo literário hebraico bíblico rabínico. Os textos foram selecionados sem pretensões e objetivos morais ou religiosos.

O objetivo principal desta pesquisa é a exposição textos da Bíblia hebraica e da literatura rabínica (tradição judaica), para que se perceba a representação da identidade masculina como progenitora e dominante, e a representação da identidade feminina como maternal, dependente, e, geradora de prole para o marido.

O tema e a abordagem escolhidos na elaboração deste artigo contribuem para estudos interdisciplinares sobre arquétipos femininos, principalmente para as pesquisas que investigam a idealização da feminilidade embasada na mulher como mãe, madre sofredora, com o objetivo principal de viver, orar e chorar, padecendo pelos seus filhos.

As informações apresentadas visam à reflexão sobre a simbologia do choro maternal. Apresenta-se o choro e a lamúria como padecimento sagrado, como um ato feminino altruísta, que em várias doutrinas e culturas transcendem a própria maternidade, percebida como sacrifício.

A leitura adicional da narrativa bíblica hebraica no idioma original é indicada para que se filtrem os sentidos que as traduções incorporam, distanciando-se dos significados das palavras hebraicas. Os números dos capítulos e versículos bíblicos hebraicos são apresentados, neste artigo, de acordo com a canonização das escrituras bíblicas hebraicas da literatura rabínica.7

\footnotetext{
${ }^{7}$ A Bíblia hebraica da literatura rabínica foi traduzida para o grego e compõe parte do Antigo Testamento da Bíblia cristã. O Antigo Testamento contém capítulos e/ou versículos adicionais em alguns livros. No Antigo Testamento, os textos posteriores ao Pentateuco estão em ordem cronológica, enquanto, na Bíblia hebraica da literatura rabínica, as escrituras hebraicas estão organizadas por temas. 0 Antigo Testamento termina com os Apócrifos, textos que não foram reconhecidos e canonizados na Bíblia hebraica da literatura rabínica.
} 
Atenção! As traduções dos versículos bíblicos para o português são realizadas diretamente do texto hebraico. Procura-se, inicialmente, apresentar os nomes originais do texto bíblico hebraico ${ }^{8}$ em itálico na medida em que sejam muito diferentes das traduções realizadas para o português. Quando necessário às traduções dos nomes hebraicos para o português encontram-se (entre parênteses). Palavras que merecem destaque, por exemplo, a palavra "chorar" neste artigo são apresentadas "entre aspas". A tradução dos versículos hebraicos para o português é livre; porque foi realizada de modo que a ordem das palavras em português siga, na medida do possível, a tradução direta das palavras hebraicas no texto original, sem necessariamente haver explicações adicionais como [adaptações gramaticais e explicações entre chaves].

\section{Bíblia e literatura hebraica rabínica}

A Bíblia hebraica é, na literatura rabínica, o Tanakh: acróstico de Torá (significa, em português, "Ensinamento"; são as escrituras do Pentateuco), Nevyim (Profetas) e Ketuvim (Escrituras). O Tanakh é conhecido na literatura rabínica como Torá SheBeKtav (Torá Escrita), que são as escrituras hebraicas redigidas em hebraico e aramaico.

De acordo com a narrativa bíblica, Moisés recebeu o Decálogo (As Tábuas da Aliança com os Dez Mandamentos) e, segundo a literatura rabínica, aprendeu a Torá no Monte Sinai. No Deuteronômio narra-se que Moisés entrega a Torá aos sacerdotes da tribo dos levitas e aos anciãos.9 Segundo a literatura rabínica, há uma discussão sobre a língua em que foram escritos os textos bíblicos hebraicos; e a hipótese de que estes textos foram redigidos em proto-hebreu e compilados pelo escriba Ezra, no quinto século antes da era comum, com os textos dos profetas e das escrituras em ketav assuri ${ }^{10}$ (caracteres assírios quadráticos). Acredita-se que

\footnotetext{
${ }^{8}$ Os nomes hebraicos bíblicos hebraicos semelhantes à tradução desses em português foram grafados de acordo com a tradição juda ica rabínica. Tabela de transliteração: A letra "h" grifada (h) tem o som do "r" fraco no início de palavra, ex: Rio de Janeiro. O som de "kh" equivale ao som de "rr" (gutural) da palavra carro. 0 som de "sh" equivale ao som de "x" de xarope.

${ }^{9}$ Deuteronômio 31:9 - "E escreveu Moisés esse Ensinamento e deu-o para os sacerdotes filhos de Levi [levitas] que levam a Arca da Aliança com Deus (Meu-Senhor: YHWH) e para todos os anciãos israelitas".

${ }^{10}$ Ketav Assuri: Escrita assíria quadrática (escrita assurita). O Talmude Babilônico, no Tratado de San'hedrin, discorre sobre o tema das letras das escrituras hebraicas israelitas.
} 
esta versão das escrituras hebraicas é reconhecida como a versão canonizada dos textos bíblicos hebraicos (na literatura rabínica). E é também a versão que foi transmitida para os centros de estudos massoretas. Posteriormente, ela integrou os textos rabínicos judaicos na diáspora, por exemplo, em Sura e Pumbedita, na Babilônia.

A primeira tradução das escrituras hebraicas para o grego ocorreu no segundo século antes da era comum. O texto ficou conhecido como Septuaginta ${ }^{11}$, por ter sido traduzido por setenta anciãos. A literatura apócrifa e deuterocanônica, inclusas em versões da Septuaginta - e canonizadas por diferentes desdobramentos do cristianismo -, não integram a versão da Bíblia hebraica da literatura rabínica. Ressaltemos que a literatura deuterocanônica não se encontra necessariamente publicada nos textos bíblicos protestantes.

A literatura rabínica é conhecida como Toshba, acróstico de Torá SheBeAlPeh (Ensinamentos Orais). Segundo a tradição judaica, esses ensinamentos foram transmitidos oralmente por Moisés para Josué e, então, de geração em geração pelos líderes do Povo de Israel até o segundo século da era comum, quando o Príncipe de Judá requisitou que fossem compilados e editados, para que não fossem esquecidos. De acordo com a tradição judaica rabínica, o Príncipe de Judá temeu que a morte dos líderes israelitas e a emergência da cultura cristã fizessem com que os ensinamentos orais da tradição farisaica, que fundamenta o judaísmo rabínico, fossem esquecidos. Portanto, segundo esse ponto de vista, se o legado da tradição farisaica não fosse redigido e editado a pedido do Príncipe de Judá no segundo século da era comum, a doutrina judaica rabínica, tal como conhecemos, não existiria. ${ }^{12}$

\footnotetext{
${ }^{11}$ A adoção da Septuaginta (tradução bíblica hebraica ao grego) desconsiderou, no cristianismo, a transmissão tradicional posterior dessas fontes pelas autoridades israelitas. Para os cristãos a Septuaginta prevalece sobre as fontes hebraicas anteriores e seus desdobramentos rabínicos hebraístas massoretas. Segundo a tradição judaica, a tradução das escrituras hebraicas para o grego foi realizada em Alexandria por judeus, devido uma imposição externa (Talmude Babilônico no Tratado Meguilá p. 9). As traduções para o grego, no judaísmo, são comparadas à idolatria e associadas à destruição do Templo de Jerusalém.

${ }^{12} \mathrm{Na}$ introdução da sua obra literária Mishne Torá, Moisés, filho de Maimon, conhecido como Maimônides e Rambam (1135-1204) apresenta a genealogia da transmissão dos textos e tradições judaicas.
} 
As leis rabínicas dos ensinamentos orais foram transcritas em seis tratados de leis judaicas, que constituem a Mishná, no segundo século da era comum. Desenvolveram-se no Talmude de Jerusalém, no quinto século da era comum, e no Talmude Babilônico, nos dois séculos seguintes. Produziu-se então uma vasta literatura rabínica em hebraico medieval no Egito, na Europa e na Ásia. Posteriormente, ela foi continuada na Europa Oriental e Israel, continuando a desenvolver-se em diferentes regiões e globalmente até hoje.

A literatura rabínica foi composta, desde os seus primórdios, por homilias como, por exemplo, o Midrash Agadá, e por exegese legislativa, como o Midrash Halakhá. Estas foram redigidas aproximadamente na época do Talmude de Jerusalém. Existem outras coleções, de autores incertos, que reúnem histórias do Talmude, por exemplo, a coletânea de textos Yalkut Shimoni, que pode ter sido escrita no século XII e foi impressa no século XVI, em Salônica (principal cidade da região grega da Macedônia).

Maimônides (século XII) redigiu o que podemos considerar a primeira enciclopédia judaica, apresentando as leis da tradição escrita e da tradição oral do judaísmo, na obra Mishne Torá. O termo mishne significa "segundo", "vice", e refere-se à importância imediata subalterna a um conceito principal. O Mishne Torá é, segundo o seu autor, o texto mais importante do judaísmo, com o objetivo de reunir os princípios e as leis da Torá ShebeKtav (Ensinamento/Tradição Escrito) e a Torá ShebeAlPeh (Ensinamento/Tradição Oral).

A série de livros do Shul'han Arukh (Mesa Posta / Mesa Arrumada / Tabela Editada), redigida pelo rabino de origem judaico-hispânica Joseph Karo (14881575), conhecido como Beth Yosef, determina as leis das tradições judaicas dos judeus sefarditas (de origem ibérica), seguidas também pelos judeus orientais, com exceção dos judeus do Iêmen. 
O rabino polonês Moses Isserles (1530-1572), conhecido como Ramó ou Rema, comentou a obra de Josef Karo e determinou as diferenças entre as leis sefarditas e as tradições judaicas asquenazitas (judeus de origem européia setentrional). O Shul'han Arukh e os comentários do Ramó para os asquenazitas fundamentam todos os tratados de leis rabínicas posteriores.

\section{Identidade feminina nos textos bíblicos hebraicos}

A primeira identidade feminina no contexto da criação da humanidade encontra-se no versículo: "E criou o Eterno Adão à sua imagem na imagem do Eterno criou-o macho-fêmea foram criados" (Gênesis 1:27)13.

A literatura exegética rabínica do livro do Midrash Gênesis Rabá 8:14 explica que o primeiro humano dos textos bíblicos hebraicos era "metade-macho" e "metade-fêmea", sem uma cisão entre eles; outros dizem que o primeiro humano era uma grande massa sem gênero.

No texto bíblico hebraico está escrito que Deus¹5, o Eterno, disse que "não é bom para Adam (Adão) estar sozinho", e fez para ele ezer kenegdo (auxílio contra ele) ${ }^{16}$. E Adão a chamou isha (mulher), porque do ish (homem) foi retirada (Gênesis 2:23) ${ }^{17}$.

\footnotetext{
${ }^{13}$ Gênesis 1:27 - "E criou o Eterno (ELOHIM) Adam (Adão) à sua imagem na imagem do Eterno (ELOHIM)". Comentários da exegese rabínica e o Livro do Zohar (referência na mística judaica - kabalá), geralmente censurados nos estudos judaicos comunitários, apontam esse versículo como a criação de uma primeira identidade feminina, que se tornou um demônio da noite cujo nome não deve ser pronunciado (o que, aliás, não consta do Gênesis), para que ela não seja chamada. Contudo, o nome desta figura feminina demoníaca, na exegese rabínica, aparece uma vez no Tanakh, em Isaías 34:14 - "E se encontraram felinos selvagens com chacais e o bode o seu companheiro chamará; contudo lá acalma-se Lilit (demônio da noite) e achou para ela descanso". Nas gerações recentes, muitas mulheres israelenses receberam esse nome.

${ }^{14}$ Midrash Gênesis Rabbá 8:1 - "E disse o Eterno (ELOHIM) façamos o humano nossa imagem e semelhança (Gênesis 1:27), Rabbi Yohanan Patah (Salmos 139:5): Posterior e anterior criei e etc., disse Rabi Yohanan se mereceu o humano, alimento de dois mundos, como dito: posterior e anterior criei, e se não ele veio para dar juízo e contas, como dito (Salmo 139:5): e ponha sobre mim sua mão, Disse Rabi Yrmiah filho de Elazar na hora que o Santificado Bendito seja Ele criou o primeiro humano, andrógeno criou-o, como está escrito (Gênesis 5:2): macho e fêmea criou-os..."

Tradução livre do hebraico e inglês para o português / site: https://www.sefaria.org/Bereishit_Rabbah.8?lang=bi?>.

${ }^{15}$ A palavra "Deus", neste contexto, equivale ao termo hebraico Adonai, que significa "Meu-Senhor", representando o tetragrama do nome divino YHWH. Este tetragrama, assim como outras palavras hebraicas, as consoantes e as vogais podem ser pronunciadas de formas diferentes, de acordo com o desenvolvimento da tradição fonética judaica de cada região.

${ }^{16}$ Gênesis 2:18 - "E disse Deus (Meu-Senhor: YHWH), o Eterno (ELOHIM) não-bom estar o Adão sozinho farei para ele auxílio contraposto a ele".

${ }^{17}$ Gênesis 2:23 - "E chamou Adão essa vez osso dos meus ossos e carne da minha carne para esta chamarei isha (mulher) porque do ish (homem) foi pega esta".
} 
A este ser chamado de isha (mulher), por ser sua extensão [extensão de Adão]: ele [Adão] deu o nome de Eva (v. nota XVI). "E chamou Adam (Adão) o nome da sua mulher Hava (Eva) porque ela foi mãe de todo o hai (vida)" (Gênesis 3:20) ${ }^{18}$. O nome Eva aparece no texto bíblico hebraico rabínico somente em duas situações: quando Adão deu esse nome à mulher e relevante a sua procriação. ${ }^{19}$

Pode-se entender então que a primeira descrição de gênero, relacionado à espécie humana, na Bíblia hebraica, ocorre em Gênesis, na criação do primeiro ser humano. Portanto, é válida a interpretação da exegese rabínica, segundo a qual o primeiro corpo humano foi criado andrógino. Eva foi criada posteriormente, a partir de uma costela do corpo andrógino do primeiro humano. E o corpo da mulher, Eva, é a matriz fundamental que detém o poder de gerar vida.

As gerações bíblicas são contadas através dos homens. Os nomes femininos aparecem quando o personagem tem expressão própria na narrativa. Por exemplo, os nomes da esposa e das filhas de Lot (Ló) não são explicitados. A esposa de Ló transformou-se em uma estátua de sal ${ }^{20}$. A filha primogênita de Ló chamou o filho que teve com o seu pai de Moab - origem dos moabitas - e a sua filha mais jovem chamou o filho que teve, com o pai, de Ben-Ami (origem dos amonitas) ${ }^{21}$.

Outras mulheres são apresentadas através da genealogia e características pessoais, sem o nome próprio. Exemplificando: a mãe do Juiz Ifttah (Jefté) é chamada de prostituta ${ }^{22}$. A própria filha de Jefté, conhecida somente como filha única de Jefté, após ir para os campos para lamentar a própria virgindade,

\footnotetext{
${ }^{18}$ Gênesis 3:20 - "E chamou Adam (Adão) o nome da sua mulher $\underline{\text { Hava }}$ (Eva) porque ela foi mãe de todo o $\underline{\text { hai }}$ (vida)".

${ }^{19}$ Gênesis 3:20 - "E chamou Adam (Adão) o nome da sua mulher Hava (Eva) porque ela foi mãe de todo o hai (vida); e em Gênesis 4:1 E Adão conheceu Eva ishto (mulher dele) e ela concebeu e pariu Caim e ela disse comprei ish (homem) com Deus (Meu-Senhor: YHWH)".

${ }^{20}$ Gênesis 19:26 - "E olhou a esposa dele [esposa de Ló] para trás e tornou-se um pilar de sal".

${ }^{21}$ Gênesis 19:31-34 - "1(11) E disse a primogênita para a jovem nosso pai velho e homem não há na terra venha sobre nós o caminho de toda a terra. ${ }^{(32)}$ Vamos embebedar nosso pai de vinho e deitaremos com ele e seremos do nosso pai semente [preservaremos a descendência do nosso pai]. ${ }^{(33)} \mathrm{E}$ embebedaram o pai delas de vinho nessa noite e veio a primogênita e deitou-se com o seu pai e não soube que deitou-se e levantou-se. ${ }^{(34)} \mathrm{E}$ foi no dia seguinte disse a primogênita para a jovem assim deitei ontem com meu pai embebedaremos de vinho também a noite e venha deitar-se com ele e seremos de nosso pai semente". A filha primogênita de Lot chamou seu filho de Moab (moabitas) e a segunda chamou o filho dela de Ben-Ami (amonitas).

${ }^{22}$ Juizes 11:1 - "E Iftah (Jefté) o guiladita era poderoso de valor e filho de mulher prostituta e nasceu para Guilad o Iftah (Jefté)".
} 
entregou sua vida como cumprimento da promessa de seu pai ${ }^{23}$. A mãe do Rei Hizkiahu (Ezequias), esposa de Ahaz (Acaz), é chamada de Abi bat Zakharia e, em outro versículo, de Abia bat Zakhariahu (Abia filha de Zacarias) ${ }^{24}$.

As versões cristãs dos textos bíblicos hebraicos geralmente apresentam uma única tradução/transcrição das variações dos nomes de personagens interpretados como um mesmo personagem no texto bíblico hebraico. Portanto, não é possível realizar um estudo apurado sobre a influência de outros idiomas e culturas nas mudanças de pronúncia e grafia dos nomes hebraicos em diferentes recortes do texto bíblico hebraico rabínico. Outra tarefa impossível é analisar as adições de sufixos com letras ao tetragrama do nome de Deus (YHWH). Transformaram-se em sufixos gregos, foram latinizados e se perderam nas demais traduções. Há outras variações interessantes dos nomes hebraicos no decorrer da narrativa do texto bíblico hebraico, que passam despercebidas nas traduções para outras línguas e particularmente para o português ${ }^{25}$.

A narrativa bíblica hebraica rabínica é abundante de personagens femininas de diferentes origens; são mulheres de caráter forte e heroínas que determinam o futuro do povo israelita. O Rei David, por exemplo, é descendente de Yehuda (Judá), quarto filho da matriarca Lea, tendo como ancestral Tamar, nora de Judá.

A narrativa sobre Tamar surpreende pelo vigor desta na missão de perpetuar a semente da família de seu marido. Ela se disfarçou de kedesha ${ }^{26}$ (meretriz), para obter a descendência através do seu sogro, Judá; ela fez com que seu sogro [Judá] a

\footnotetext{
${ }^{23}$ Juízes 11:38 e 39 - " ${ }^{(38)}$ E ele disse vá e enviou ela dois meses e foi ela e suas companheiras e "chorou" pela virgindade dela sobre as montanhas. ${ }^{(39)}$ E terminou dois meses e retornou para seu pai e ele fez [cumpriu] para ela a promessa que prometeu e ela não conheceu homem e foi decreto em Israel".

${ }_{24}^{2} 2$ Reis 18:2 - "Na idade (filho com / na idade de) [Hizkiahu = Ezequias filho de Acaz / citado no versículo 2 Reis 18:1] de vinte e cinco anos em seu reino e vinte e nove anos reinou em Jerusalém e o nome de sua mãe Avi filha de Zakharia". E em 2 Crônicas 29:1 "Hizkiahu rei (filho com / na idade de) vinte e cinco anos e vinte e nove anos reinou em Jerusalém e sua mãe Avia filha de Zakhariahu". ${ }^{25}$ Por exemplo, Potifar e Poti Fera nas traduções recebem um nome só, porque são interpretados como o mesmo protagonista. (Vide Gênesis 37:36 e outros: "136 Es midianitas venderam-no para o Egito para "Potifera" oficial do Faraó ministro da 'da guarda real' [a palavra escrita em hebraico, Tabahimim, significa literalmente 'abatedores' e também 'cozinheiros' / podendo ser um ministro para pecuária]". Gênesis 41:45 - "E chamou Faraó o nome de Yosef (José) Tzafnat Paneah e deu para ele Asnat filha de Poti Fera sacerdote Onen como mulher e saiu Yosef (José) sobre a terra do Egito".

${ }^{26}$ Gênesis 38:21 - "E perguntou para as pessoas do lugar dizer onde está a meretriz (hakedesha) ela em Einaim no caminho e disseram não estava nesse (aqui) meretriz". Este versículo de Gênesis é no mínimo interessante uma vez que está escrito no Deuteronômio 23:18: "Não haverá meretriz nas filhas de Israel e não existirá meretrício dos filhos de Israel". A identificação Hakedesha é usada para denominar alguém designada e disponível para prostituição.
} 
engravidasse, uma vez que ela ficou viúva de dois dos três filhos dele e ele não lhe concedeu ao seu terceiro filho ${ }^{27}$.

Existem muitas personagens importantes e nomes femininos israelitas e não israelitas na Bíblia hebraica. Há inclusive homônimas, por exemplo, Abigail - irmã do Rei David (I Crônicas 2:15 e 16) ${ }^{28}$, e Abigail - esposa de Nabal, que se casou com o Rei David após o falecimento do marido (I Samuel 25:3 e 25:14) ${ }^{29}$.

Tamar é o nome de mais de uma personagem no texto bíblico hebraico. A primeira Tamar é a ascendente do Rei David; ela teve dois filhos com Judá, filho de Jacob. A segunda Tamar foi enviada pelo Rei David para o seu filho Amnon, que a violentou, estuprou e enxotou. Avshalom ${ }^{30}$ (Absalom), irmão de Tamar e de Amnon, acolheu Tamar, sua irmã violentada, e, como vingança, causou a morte de Amnon 31. Absalom deu o nome Tamar à sua filha, sendo essa a terceira personagem de nome Tamar na Bíblia hebraica. ${ }^{2}$

Ruth (Rute), a moabita, é avó do Rei David. Ela ficou viúva do filho de Naomi e migrou com a sua sogra, que retornava das terras dos moabitas (ao leste do Rio Jordão) para as terras da família de seu marido (ao oeste do Rio Jordão) em Bet-Lehem (Belém). Auxiliada por Naomi, Rute conseguiu que Boaz, detentor das terras onde ela trabalhava a resgatasse, para que ela concebesse descendência para a família de sua sogra 33. Segundo a tradição judaica, o Messias - Mashiaḩ, em

\footnotetext{
${ }^{27}$ Gênesis 38:6,7,8,9,10,11 - "'(6) E pegou Judá uma mulher para Er seu primogênito e seu nome Tamar. ${ }^{(7)}$ E foi Er o primogênito de Judá mau nos olhos de Deus (Meu-Senhor: YHWH) e matou-o Deus (Meu-Senhor: YHWH). ${ }^{(8)}$ E disse Judá para Onen vá para a mulher do teu irmão e levirate [dê a tua semente à viúva de seu irmão sem filhos] para ela e erga semente para o teu irmão ${ }^{(9)}$ E soube Onen que não seria dele a semente [descendência] e foi para a esposa de seu irmão e destruiu no chão sem dar a semente por seu irmão. ${ }^{(10)} \mathrm{E}$ mal nos olhos de Deus (Meu-Senhor: YHWH) o que fez e matou também ele. ${ }^{(11)}$ E disse Judá para Tamar sua noiva sente viúva na casa de teu pai até que cresça Shela meu filho porque disse para que não morra também ele como os irmãos dele e foi Tamar e sentou [morou] na casa de seu pai".

${ }^{28}$ I Crônicas 2:15,16 - " "(15) Otzem o sexto e David o sétimo. ${ }^{(16)}$ E a irmã deles Tzuriá e Abigail e os filhos de Tzruriá Avishai e loav e Asa hel três".

${ }^{29}$ I Samuel 25:3 - "E o nome do homem Nabal e o nome da mulher dele Abigail e a mulher boa de cabeça e bonita de descrição e o homem difícil e ruim de feitos e era da casa de Caleb", e; I Samuel 25:14 - "E para Abigail mulher de Nabal contou um jovem dos jovens dizendo: eis enviou David mensageiros do deserto para abençoar o nosso senhor e ele encobriu-os (vestiu-se sobre eles = rebaixou-os). ${ }^{30}$ Curioso notar que o nome Avshalom (Absalom) significa em português "pai da paz".

${ }^{31}$ II Samuel 13:10, 11, 12, etc. - "1(10) E disse Amnon para Tamar traga-me comida no quarto e comerei da tua mão e pegou Tamar os bolos que fez e trouxe para Amnon seu irmão no quarto. ${ }^{(11)}$ E serviu para ele para comer e segurou nela e disse para ela deite-se comigo minha irmã. ${ }^{(12)}$ E disse para ele negativo irmão não me torture porque não farei isso em Israel não faça essa degeneração, etc."

32 II Samuel 14:27 - "E nasceram para Absalom três filhos e uma filha e seu nome Tamar ela era mulher bonita de aparência".

${ }^{33}$ Escrituras hebraicas - Livro de Rute: estudado tradicionalmente nas comunidades rabínicas todos os anos antes da festividade que lembra a outorga dos dez mandamentos (Shavuoth).
} 
português, significa "ungido" - será descendente do Rei David, portanto existirá também por mérito dessas mulheres.

As escrituras bíblicas hebraicas apresentam muitas personagens femininas, nomes femininos que são citados como referências familiares. Apresentam também nomes de mulheres que demonstram coragem e força e determinam o futuro de suas famílias e a descendência dessas (e de todos os israelitas). Independentemente do gênero do (a)s personagens; narrativas sobre homens e mulheres são apresentadas expondo-se o seu afinco aos ideais dos líderes das escrituras hebraicas rabínicas, com vitórias estratégicas e militares para os israelitas. Não é necessário, neste artigo, listar todos os nomes femininos das escrituras bíblicas hebraicas rabínicas, que podem ser facilmente encontrados em ordem alfabética em enciclopédias populares na internet, com hiperlink para os versículos em que são citados.

A identidade feminina, criada juntamente com a identidade masculina, no primeiro humano, a matriz feminina de mulher geradora da humanidade e outras contextualizações vinculadas ao status do gênero sexual feminino, no texto bíblico hebraico, recebem uma nova e precisa descrição, muito ilustrativa, no Livro de Provérbios 12:4 da Bíblia hebraica. Neste versículo, a mulher virtuosa é descrita como o adorno da testa de seu dono [traduzido como a coroa de seu marido]; a mulher que envergonha seu dono é identificada como podridão dos ossos dele. A palavra hebraica baal, que significa "dono", é usada até os dias de hoje para "marido".34

\section{Choro na Bíblia hebraica}

O choro e as lágrimas representam comoção e desolamento. O choro na Bíblia hebraica não é restrito à figura feminina. O choro do desolado revela comoção de dor, de lamúria e de lamento. O choro pode ser interpretado como

\footnotetext{
${ }^{34}$ Provérbios 12:4 - "Mulher-virtuosa grinalda [enfeite circundante da cabeça] de seu marido [seu dono] e podridão de seus ossos se envergonha".
} 
resposta a uma situação lastimável que desperta e clama por piedade. Revela também a superação da amargura de uma dificuldade. As palavras investigadas no texto hebraico foram os vocábulos derivados do conceito bekhy, do verbo hebraico lvkot, que em português significa "chorar", e do conceito ybab, que significa "chorou (balbuciou, choramingou) como criança", comparável ao "buá" infantil em português.

Homens e mulheres de diferentes idades, e, não somente israelitas, choram. Todos os dias no salmo que precede a reza após a refeição de pão os leitores lembram que devem chorar por Sião: "Nos rios babilônicos lá habitávamos e chorávamos ao nos recordar de Sião (Salmos 137:1-5)".

Um exemplo redundante de choros e lamúrias é o Livro de Lamentações. Citemos outras situações: Avraham (Abraão) chora a morte de sua esposa Sara (Gênesis 23:1-2); Yosef (José) chora perante seus irmãos (Gênesis 43:30); os filhos de Israel "gritam" - não está escrito "choram", originalmente, pela opressão dos egípcios sobre eles (Êxodo 3:9); Raquel "chora-se" pelos filhos que já não mais estão [vivem] em Yermiah̆u (Jeremias 31:14 na versão rabínica / versículo 15 na versão cristã); até figuras inanimadas choram, por exemplo: a cidade de Jerusalém "chora" pela destruição e pelos seus filhos (Lamentações 1:2, 3 e Lamentações 1: 16). 35

\footnotetext{
${ }^{35}$ Salmos 137:1-5 - "1(1) Nos rios da Babilônia lá habitamos também choramos ao lembrarmo-nos de Sião. ${ }^{(2)}$ Sobre os salgueiros no meio dela penduramos nossas harpas. ${ }^{(3)}$ Porque lá nos pediram aqueles que nos mantinham cativos palavras-música e nossos atormentadores [pediam] alegria [dizendo] cantem para nós das músicas de Sião. ${ }^{(4)}$ Como cantaremos a música de Deus (Meu Senhor: YHWH) sobre terra estrangeira. ${ }^{(5)} \mathrm{Se}$ eu esquecer de ti Jerusalém esquecerei a minha destra [direita / destreza]"; Gênesis $23: 1,2$ - "1(1) E foi a vida de Sara cem anos evinte anos e sete anos os anos da vida de Sara. ${ }^{(2)}$ E morreu Sara em Kriat Arba [que é] ele/ela Hebron na terra de Canaã e veio Abraão homenagear Sara e chorar por ela"; Gênesis 43:30 - "E apressou-se José porque lamentaram sua misericórdia pelos seus irmãos e pediu para chorar e veio para o quarto e chorou lá"; Êxodo 3:9 - "E agora eis grito dos filhos de Israel vem à mim e também vi a (o)pressão que os egípcios pressionam eles"; Jeremias 31:14 - "Assim disse Deus (Meu-Senhor: YHWH) a voz em Ramá escutada eis choro tamrurim [amargo / que chama a atenção] Raquel chora-se pelos seus filhos mane [tristeza entendida como recusa] consolo pelos seus filhos porque eles não estão"; Lamentações 1:2, 3 - "(2) Ela chorou choro na noite e suas lágrimas sobre suas bochechas não tem para ela consolo de todos que gostam dela todos seus companheiros à traíram e se tornaram para ela inimigos. ${ }^{(3)}$ Exilou-se Judá dos olhos e da maior servidão ela habita entre os gentios (povos) não encontra descanso todos-que-aperseguem à alcançam entre as suas limitações", e; Lamentações 1:16- Por isso eu (estou) chorosa nos meus ol hos, dos meus olhos desce água porque distanciou-se de mim o consolador que devolve minha alma e estiveram meus filhos desolados porque fortaleceu-se o inimigo".
} 
A referência do texto hebraico massoreta no idioma original é importante, porque as traduções raramente conseguem converter para os outros idiomas propriedades linguísticas peculiares ao hebraico. As variações gráficas e ortográficas que compõem o texto bíblico hebraico consagrado, canonizado, influenciam a compreensão e mesmo a estética do texto. Pode-se ilustrar o que afirmamos com um detalhe envolvendo a morte de Sara e a conseqüente tristeza de Abraão: este "chorou" quando a esposa morreu. Mas, no texto bíblico hebraico massoreta, a palavra lvkota (chorou por ela) está grafada com uma das letras com tamanho intencionalmente reduzido (a letra kaf) ${ }^{36}$

A exegese rabínica explora o significado da mudança de tamanho das letras no texto massoreta e dá diferentes sentidos para essas manifestações peculiares. Abraão chorou por Sara com uma letra menor, variação essa normalmente desconhecida para grande parte dos leitores das traduções convencionais.

\section{Choro feminino na Bíblia hebraica}

O choro feminino na narrativa bíblica hebraica aparece em diversos episódios: 1) Hagar, mãe de Ismael, "chora"; 2) Na exegese rabínica da literatura judaica consta que os olhos da matriarca israelita Léa eram macios porque ela "chorava"; 3) As reféns de guerra "choram"; 4) A mãe do rei cananeu Sisera "chora" como uma criança ao saber da morte de seu filho; 5) A filha do guerreiro Jefté "chora" pela sua virgindade; 6) As filhas de Israel "choram" pela morte do rei Saul; 7) As viúvas "choram"; 8) Noemi, Orfá (nora de Noemi que, segundo a tradição judaica, é avó do gigante Golias) e Rute (a avó do rei David) "choraram" quando todas, viúvas, deviam se separar, porque Noemi resolveu retornar da terra dos moabitas para a Judéia, terra da família de seu marido, e foi acompanhada pela sua nora Rute; e 9) Raquel, a matriarca israelita que morreu ao dar à luz o seu segundo filho, Benjamim, é conhecida, no texto bíblico hebraico, bem como na tradição e na cultura judaica, como "a mãe que chora pelos seus filhos".

\footnotetext{
${ }^{36}$ Gênesis 23:2 - "E morreu Sara em Kriat Arba que é Hebron na terra de Canaã e veio Abraão elogiar Sara e chorar por ela".
} 
Quando acabou a água do cantil, Hagar - a serva de Sara - colocou seu filho Ismael sob um arbusto e afastou-se para não vê-lo morrer. Hagar elevou sua voz e "chorou". E um anjo avisou a Hagar que não tivesse medo, porque "o Eterno escutou a voz do jovem de onde ele está" (Gênesis 21:15-17)37.

A profetisa, guerreira e juíza Débora é criticada na exegese rabínica. Débora se apresenta como a mãe que por Israel se ergueu [salvação de Israel] $3^{8}$ e não como a mãe que seu mérito é entendido como o padecimento de "chorar" pelos seus queridos.

Jefté de Guilad, filho da meretriz, prometeu sacrificar a primeira coisa que visse sair de sua casa, se ele retornasse vitorioso da guerra. A primeira a sair para recebê-lo, quando ele voltou, foi a sua filha única, comemorando com danças e batuques. Antes do sacrifício, foi concedido à sua filha "chorar" pela sua virgindade (Juízes 11:37-38)39.

O "choro" pela virgindade, e não pela vida e morte, fundamenta a exegese do sacrifício prometido por Jefté na consagração de sua filha, confinando-a ao isolamento e impingindo-lhe o impedimento à maternidade e a interdição de gerar descendentes. Segundo a exegese rabínica, o encarceramento e o claustro representam a interrupção e impossibilidade da continuação da vida, e não a morte física imediata.

\footnotetext{
${ }^{37}$ Gênesis 21:15-17 - "1(15) E foi-se a água do cantil e enviou a criança sob um dos arbustos. ${ }^{(16)}$ E foi-se e sentou-se de frente a distância do tiro de um arco porque disse não verei a morte da criança e sentou-se de frente e elevou sua voz e chorou. ${ }^{\text {(17) }}$ E escutou o Eterno (ELOHIM) a voz do jovem e chamou o anjo do Eterno (ELOHIM) Hagar dos céus e disse para ela o que para você Hagar não tema por que escutou o Eterno (ELOHIM) a voz do jovem que ele está lá".

${ }^{38}$ Juízes 5:7 - "E cessaram as aldeias [cidades sem muralhas ao redor] em Israel; cessaram até que levantai-me Débora que levantai-me mãe em Israel".

${ }^{39}$ Juízes 11:37-38 - "1(37) E disse para o seu pai será feita para mim essa coisa deixe-me ir dois meses e irei e descerei as montanhas e chorarei a minha virgindade eu e minhas companheiras. ${ }^{(38)}$ E disse vá e ele enviou ela dois meses e foi ela e suas companheiras e chorar a sua virgindade sobre as montanhas".
} 


\section{A mãe que chora na Bíblia hebraica}

Lê-se que Hana (Ana), esposa de Elcaná e mãe do profeta Samuel, "chorava"quando foi repreendida pelo Sumo Sacerdote Eli no Templo de Jerusalém, pela maneira que movia seus lábios em suas preces para gerar um filho(I Samuel 1:7-15)40. Hana, a mulher infértil de Elcaná, "chorou" desoladamente, acalmando-se após ser abençoada pelo sumo sacerdote Eli. Ao ter

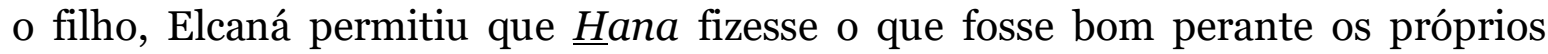
olhos, e, quando ela terminou de amamentar o filho, levou-o para crescer no

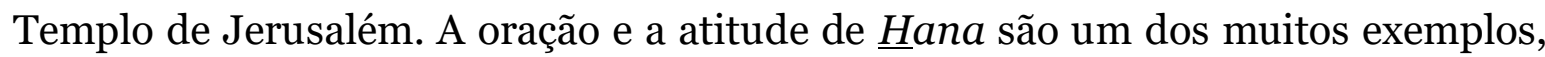
no texto bíblico hebraico, que fundamentam a missão feminina judaica de rezar para gerar filhos e encaminhá-los para que vivam corretamente e para a perpetuação dos preceitos da doutrina religiosa.

A matriarca israelita Rahel (Raquel), esposa do patriarca Jacob (posteriormente chamado Israel), representa, no e para o judaísmo, a mãe que "chora" pelos seus filhos: Rahel Imênu ("Raquel nossa mãe”). O marco do túmulo de Raquel, próximo a Jerusalém, nas cercanias da cidade de Belém, entre o território de Israel e o território da Autoridade Palestina, necessitou da construção, por parte de Israel, de um muro especial para defender milhares de fiéis, principalmente judeus ortodoxos, que peregrinam para esse local todos os meses e

\footnotetext{
${ }^{40}$ I Samuel 1:7-15 - ${ }^{(7)}$ "E assim fazia ele de ano em ano quando subia à casa de Deus (Meu-Senhor: YHWH) e assim a enervava (a outra esposa) e chorava e não comia. ${ }^{(8)} \mathrm{E}$ disse para ela Elcaná mulher Hana (Ana) por que choras e por que não comes e por que está mal o teu coração não sou eu bom para ti do que dez filhos. ${ }^{(9)}$ E levantou-se Hana (Ana), depois de terem comido em Shiló e depois de terem bebido e Eli o sacerdote sentado sobre a cadeira no pilar da porta do Templo de Deus (Meu-Senhor: YHWH). ${ }^{(10)} \mathrm{E}$ ela com amargura de alma orou para Deus (Meu-Senhor: YHWH) e chorou pranteando. ${ }^{(11)}$ E prometeu e disse Deus (Meu-Senhor: YHWH) dos Exércitos se enxergar e ver nos olhos de tua serva e te lembrares de mim e não te esqueceres de tua serva e deres a tua serva semente de homens e darei ele para Deus (Meu-Senhor: YHWH) todos os dias da vida dele, e navalha não subirá sobre a cabeça dele. ${ }^{(12)} \mathrm{E}$ sucedeu que multiplicando ela em orar perante Deus (Meu-Senhor: YHWH) e Eli observou a sua boca. ${ }^{(13)} \mathrm{E}$ Hana (Ana) ela falava de coração só seus lábios se moviam e sua voz não se ouvia e a pensou Eli por embriagada. ${ }^{(14)} \mathrm{E}$ disse para ela Eli até quando te embriagarás retire o teu vinho de sobre ti. ${ }^{(15)}$ E respondeu Hana (Ana) e disse não meu-senhor mulher difícil-espírito eu e vinho e bebida forte não bebi e derramo a minha alma perante Deus (Meu-Senhor: YHWH)".
} 
em dias próximos as festividades judaicas. Raquel faleceu após o parto do seu segundo filho, no primeiro livro da narrativa bíblica hebraica (Gênesis 35:16-20).41

Raquel, "a mãe lamuriosa", no judaísmo, representa a figura maternal suprema e sofredora, que "chora" pelos filhos, e, por isso, é enaltecida pelos seus fiéis; apesar de ser a mãe somente de dois dos doze filhos e uma filha do patriarca Jacob. Raquel é referida, nos últimos textos bíblicos hebraicos (Livro do Profeta Jeremias) como "a mãe que chora pelos seus filhos" (Jeremias 31:14).42

A sepultura de Raquel ilustra o impacto da difusão de uma figura maternal judaica. Raquel teve os dois filhos mais novos, dentre os doze filhos e uma filha do patriarca Jacob com quatro mulheres, e faleceu ao nascimento de seu segundo filho. Contudo, o Livro de Jeremias relata que a matriarca Raquel "chora" pelos seus filhos.

\section{Mulher de valor e mãe chorosa na literatura rabínica}

"Todas as pessoas da casa de Jacob que vieram ao Egito setenta [setenta pessoas da família de Jacob migraram para o Egito] (Gênesis 46:27)". O conceito Beit Yaacov (casa de Jacob), na literatura rabínica, representa o poder feminino na coletividade judaica. O poder masculino é assertivo, opõe-se ao profano e à falta de santidade no mundo. O poder feminino representa uma capacidade acolhedora, que destina a mulher a abrigar a santidade de acordo com os preceitos rabínicos, garantindo a segurança do lar (VESHINANTAM, 2018, p. 37).

\footnotetext{
${ }^{41}$ Gêneseis 35:16-20 - " ${ }^{(16)}$ E partiram de Bet-El e havendo ainda um pequeno pedaço de terra para chegar em Efrata e pariu Raquel e teve dificuldade no parto. ${ }^{(17)} \mathrm{E}$ foi na dificuldade no parto e disse para ela a parteira não tema que esse também para ti um filho. ${ }^{(18)} \mathrm{E}$ foi na saída de sua alma porque ela morreu e chamou o nome dele Ben-oni (filho-da minha tristeza) e seu pai chamou-o Benyamin*. ${ }^{\text {(19) }}$ E terminou Raquel e foi enterrada no caminho de Efrata que é Beth Lehem". ${ }^{(20)}$ E lapidou Jacob a lápide sobre seu túmulo; essa é a lápide do túmulo de Raquel até hoje. *Benyamin = filho destro [da minha direita].

${ }^{42}$ Jeremias 31:14 (observação: Jeremias 31:14 na versão da Bíblia hebraica rabínica / No Antigo Testamento (cânone cristão) esse texto encontra-se no versículo seguinte, ou seja, em Jeremias 31:15) - "Assim disse Deus (Meu-Senhor: YHWH) a voz em Ramá escutada eis choro tamrurim [amargo / que chama a atenção] Raquel chora-se pelos seus filhos mane [tristeza entendida como recusa] consolo pelos seus filhos porque eles não estão".
} 
O hábito de cantar Eshet Hail, do livro Provérbios 31: 10-31 da Bíblia hebraica, título entendido em português como "Mulher de Valor", impresso em todos os livros de liturgia judaica ortodoxa, entoado em voz alta antes da primeira refeição do shabat 43 , ilustra a doutrinação através do louvor e de manifestações artísticas populares entre os judeus ortodoxos que revelam a perpetuação de uma

hierarquia de valores em suas atividades diárias, de seus hábitos, da arte que produzem que fortalece o domínio masculino sobre a identidade feminina através de suas tradições.

O texto traduzido abaixo mostra que o valor da mulher judia não é o encanto e a beleza; é justamente a força de seu trabalho contínuo e intenso pela sua casa e pela família:

Quem pode encontrar uma mulher virtuosa? Seu valor excede em muito o das jóias. O coração de seu esposo confia nela, benefício não the há de faltar. Ela o trata com bondade, nunca com maldade, todos os dias de sua vida. Ela procura lã e linho e trabalha de bom grado com suas mãos. Ela é como os navios mercantes; traz seu alimento de longe. Levanta-se enquanto ainda é noite, alimenta seu lar e estabelece as tarefas para suas criadas. Ela avalia um campo e o adquire; de seu lucro planta um vinhedo. Ela cinge seus lombos com a força e dobra os braços.

Ela está ciente de que seu empreendimento é proveitoso; sua lâmpada não se apaga à noite. Ela põe suas mãos sobre o fuso, e suas palmas empunham a roca [de fiar]. Ela oferece sua mão ao pobre, e estende suas mãos ao necessitado. Ela não teme por seu lar durante o frio, pois toda sua família está vestida [e aquecida] com lã escarlate. Ela faz sua própria tapeçaria; suas vestes são de fino linho e púrpura. Seu marido é famoso nos portais, quando ele senta-se com os anciãos da terra. Ela fabrica roupa branca e [a] vende, ela provê cinturões aos mercadores. Força e dignidade são seus trajes; ela olha sorridente para o futuro. Abre sua boca com sabedoria e o ensinamento da bondade está sobre sua língua. Ela observa a conduta de seu lar e não come o pão da ociosidade. Seus filhos levantamse e a aclamam; seu marido a enaltece [dizendo]: "muitas filhas têm feito obras meritórias, porém tu superaste a todas elas! O encanto é enganoso e a beleza nada vale; uma mulher temente a D'us é a que deve ser louvada. Elogiem-na por suas realizações, e que suas obras louvem-na nos portões.44 (YAGEL, 2014. p. 168-169).

\footnotetext{
${ }^{43}$ Shabat é o sétimo dia da semana no judaísmo com duração do pôr do sol da sexta feira até o surgimento das primeiras três estrelas na noite de sábado.

${ }^{44}$ Eshet Hail é um poema redigido pelo rabino italiano Abraham Yagel (1553-1623) em Veneza em 1606. Esse poema faz parte do texto da liturgia judaica de sexta-feira à noite.
} 
No Talmude Babilônico, narra-se um evento que ensina dramaticamente que o homem não deve ocasionar "o choro de preocupação" da mulher: Rav Rehumi normalmente estudava perante Rava (líder da comunidade), na cidade de Mehuza, e tinha o costume de voltar para sua casa, anualmente, na véspera do Yom Kippur (conhecido como Dia do Perdão). Um dia ele [Rav Rehumi] estava especialmente concentrado na halakhá (lei judaica) que estudava, que ficou entretido e não foi para casa. Sua esposa estava esperando por ele e continuamente dizia para si mesma: "Agora ele está vindo, agora ele está vindo". Mas ele não veio. Ela ficou angustiada com isso e "uma lágrima caiu de seu olho". Naquele exato momento, Rav Rehumi estava sentado no telhado e o telhado debaixo dele desabou, causando-lhe a morte. Essa narrativa ensina que uma pessoa deve ser cuidadosa; ele [Rav Rehumi] foi severamente punido por ter causado sofrimento à sua esposa, mesmo não sendo essa a sua intenção. 45

No Talmude Babilônico consta que uma vez um herege perguntou para uma mulher chamada Berurya ${ }^{46}$ sobre a citação em Isaias 54:147, que está escrito: "Alegre-se estéril que não pariu, abra-se em alegria e exclame porque não teve trabalho de parto...": significa que a mulher que não pariu deve comemorar? Berurya respondeu para o escárnio herege: "Tolo! Vá até o final do versículo e veja que está escrito: "Os filhos das desoladas serão mais numerosos que os filhos das mulheres casadas, disse o Senhor".

Berurya explicou que o significado de: "Cante, mulher estéril que não pariu", significa: "cante congregação de Israel, que é como uma mulher estéril, que não pariu filhos e são destinadas ao Inferno como você".48

\footnotetext{
${ }^{45}$ Talmude Babilônico no Tratado Ketubot página 62b parágrafo 4.

$<$ https://www.sefaria.org/Ketubot.62b.4?lang=bi>.

${ }^{46}$ Berurya é o nome de uma mulher.

${ }^{47}$ Isaias 54:1- Alegre-se estéril (mulher estéril) que não pariu, abra-se em alegria e exclamações porque não adoeceu (teve trabalho de parto) porque muitos mais são os filhos das desoladas do que os filhos das mulheres de seus donos (casadas) disse Deus (Meu-Senhor: YHWH).

${ }^{48}$ Talmude Babilônico no Tratado Brakhot 10A - <https://www.sefaria.org/Berakhot.10a>.
} 


\section{Conclusão}

A idealização maternal da mulher que padece pelos filhos faz parte do inconsciente coletivo do imaginário popular judaico e cristão. As rezas cristãs à figura feminina da Virgem Maria, mãe de Jesus, e as orações judaicas à Matriarca Raquel, são manifestações literárias que enaltecem a figura feminina da mulher como mãe necessariamente zelosa pelos seus filhos.

Os ideais do sufrágio universal e da globalização dos meios de comunicação tornam importante incentivar o desenvolvimento de pesquisas que investiguem sem preconceitos e analisem, com crítica exacerbada, a complexidade de manifestações literárias e expressões culturais sobre mitologias e símbolos sexistas e demais estereótipos na literatura em diferentes idiomas, crenças, religiões, culturas e doutrinas nos mais variados contextos sociais.

Este estudo é importante para que se tenha maior consciência da complexidade dos valores sexistas dominantes e conflitos culturais misóginos que depreciam características sexuais nas mais diversas tradições e ambientes sociais. Pois pessoas, cidadãos, oriundos de países que reconhecem os princípios do sufrágio universal, podem enganosamente crer que seus princípios humanos são valores universais reconhecidos e respeitados globalmente, quando, de fato, os costumes regionais e tradições culturais antigas predominam em diversos lugares e países.

Nas leis constitucionais dos países islâmicos, exceto no Marrocos que a monarquia se sobrepõe aos movimentos clericais, por exemplo, na Autoridade Palestina, a Lei Básica Nacional Palestina (Constituição da Autoridade Palestina): declara a supremacia dos princípios religiosos islâmicos da Shari'a sobre as leis constitucionais palestinas. O Artigo $4^{49}$ traz que: 1) a religião oficial é o islã e que outras religiosidades devem ser mantidas; 2) os princípios islâmicos da Shari'a são

\footnotetext{
${ }^{49}$ Palestinian Basic Laws - Art. 4: 1) Islam is the official religion of Palestine. Respect for the sanctity of all other divine religious shall be maintained. 2) The principles of Islamic Shari'a shall be a principal source of legislation. 3) Arabic shall be the official language.
} 
a fonte principal de legislação; e 3) o árabe é o idioma oficial. O Artigo $185^{\circ}$ garante a liberdade de credo, adoração e religião, independentemente de raça, sexo, cor, religião, movimento político ou deficiências físicas, que não violem a ordem e moralidade pública. Assim, a Shari'a é o texto fundamental, acima de todas as leis constitucionais palestinas, que fundamenta oficialmente a ordem pública e sanciona os padrões morais, relações familiares e determina os deveres masculinos e femininos como complementares. Os direitos masculinos e femininos constitucionais são hipoteticamente equivalentes, contudo são absolutamente desiguais, porque a Shari'a ordena a inclusão social estritamente através de tarefas determinadas pelas identidades sexuais: o homem é portador de alma no islã e é o responsável pelo sustento, enquanto a mulher não tem alma é direcionada, pelo muçulmano, para práticas exclusivamente machistas; devendo cumprir seus deveres conjugais e cuidar da educação infantil no lar.

No cristianismo, mitos populares com imagens femininas são adaptados, apropriados e reconhecidos como as revelações da Virgem Maria [a mulher virgem e casta que pariu o deus menino Jesus], ou seja, da Maria, Mãe de Deus, que ora pelos pecadores tanto agora quanto na hora da morte, atrai os fiéis de uma mãe piedosa que em prantos reza pelos seus crentes.

A palavra "madre" significa "mãe". A consagração à vida religiosa transforma mulheres que se declaram abstêmias de relações carnais em irmãs e "madres" de instituições religiosas. A "madre católica apostólica romana" é o ícone da castidade feminina que caracteriza a "mãe virtuosa, ideal e piedosa". Esta figura "maternal", uma mulher casta que faz parte do clero de uma instituição religiosa, ilustra o imaginário popular que associa a pureza maternal à mulher sem prazeres carnais, dedicada à missão de orar, cuidar e "chorar" [prantear] pelos filhos. As madres das diferentes instituições católicas apostólicas romanas trajam roupas clericais muito semelhantes às vestes das mulheres castas do antigo templo romano de Juno.

\footnotetext{
${ }^{50}$ Palestinian Basic Laws - Art.18: Freedom of belief, worship and performance of religious functions are guaranteed, provided public order or public morals are not violated.
} 
O poeta português Coelho Neto, no final do século XIX, inspirou-se na frase "Ser mãe é padecer num paraíso", supostamente dita para Maria em um momento difícil na Via Sacra, redigindo o seguinte poema:

\author{
Ser Mãe \\ Ser mãe é desdobrar fibra por fibra \\ O coração! Ser mãe é ter no alheio \\ Lábio, que suga, o pedestal do seio, \\ Onde a vida, onde o amor cantando vibra. \\ Ser mãe é ser um anjo que se libra \\ Sobre um berço dormido; é ser anseio, \\ É ser temeridade, é ser receio, \\ É ser força que os males equilibra! \\ Todo o bem que a mãe goza é bem do filho, \\ Espelho em que se mira afortunada, \\ Luz que lhe põe nos olhos novo brilho! \\ Ser mãe é andar chorando num sorriso! \\ Ser mãe é ter um mundo e não ter nada! \\ Ser mãe é padecer num paraíso! (COELHO NETO). ${ }^{1}$
}

Este artigo apresentou a tradição hebraico-cristã, em que a fêmea é, inicialmente, integrada ou fundida ao homem, no primeiro humano, "macho-fêmea criou-os" (Gênesis 1:27). Depois, é mulher, matriz geradora da humanidade (ainda no Livro de Gênesis). Torna-se, no Livro de Provérbios (12:4), o “ornamento da testa do marido ou podridão de seus ossos" (Provérbios 12:4).

A pesquisa realizada teve como proposta e cumpre o objetivo de incentivar que sejam desenvolvidas pesquisas adicionais sobre manifestações sexistas e de misoginia em diferentes textos e contextos. Investigar essas manifestações permite aprender os valores sexistas de diferentes universos simbólicos e discutir seus preconceitos. A pesquisa textual e o exercício da alteridade (tentativa de colocar-se no lugar do outro como ele é) colaboram para o desenvolvimento de demais estudos com o objetivo de perceber os valores sexistas e misóginos e diagnosticar o impacto de linguagens, padrões e desenvolvimento de leis discriminatórias nos diferentes países.

\footnotetext{
${ }^{51}$ Henrique Maximiano Coelho Neto (Caxias - MA, 1864-1934): Romancista escreveu um dos mais famosos sonetos da língua portuguesa - "Ser mãe". Torquato Neto no soneto "Mamãe Coragem" interpretado por Gal Costa em Tropicália.
} 
Vale terminar este artigo com um alerta, no sentido de não censurar nem adaptar textos antigos. Cada texto deve então ser lido sob uma óptica de análise crítica, que perceba todas e quaisquer manifestações culturais como fragmentos culturais que resultaram de contextos temporais geográficos, históricos e sociais específicos.

No machismo tudo que é tido como feminino é sinônimo de fragilidade. O feminismo não deveria ser representado pela queima de sutiãs, ou pela negação de qualquer feminilidade e sim pela liberdade de usar ou não sutiãs e pelo reconhecimento das capacidades pessoais, pela valorização do humano, sem preconceitos sexistas. Todos, inclusive travestis e transexuais, na sociedade machista aprendem ter aversão as características essenciais femininas. No paradigma machista a menstruação não é associada à renovação e o seu sangue a vida. O sangue da menstruação é associado à morte, à sujeira e à impureza. Já o sêmen, nesse mesmo contexto machista, representa vigor. Em diferentes religiões o ato de derramar sêmen fora de uma relação conjugal e para procriar é abominado porque a ejaculação representa vida.

Para desconstruir preconceitos racistas, fobias à diversidade de sexualidades, machismos, misoginia, feminismos estereotipados e demais estereótipos sexistas, devemos analisar criticamente todas as tradições e manifestações culturais que impulsionam a opressão que invadem, violentam e matam pessoas, que agridem quaisquer características sexuais, pois a liberdade de expressão deve fundamentar-se em maneiras de não humilhar os outros.

\section{REFERÊNCIAS}

ALHATORA.ORG. Mikraot gedolot. Disponível em: <https://mg.alhatorah.org/>. Acesso em: 22 mar. 2019.

ALQURAN. Disponível em: <https://quran.com/>. Acesso em: 15 fev. 2019.

BÍBLIA HEBRAICA. Disponível em: <https://www.sefaria.org>. Acesso em: o2 dez. 2018. 
BOURDIEU, Pierre. A dominação masculina. Rio de Janeiro: Bertrand, 2012.

BOURDIEU, Pierre. O poder simbólico. Rio de Janeiro: Bertrand Brasil, 1992.

HARARI, Yuval Noah. Sapiens: a brief history of humankind. Panamá: Penguin Random House Company, 2014.

MAIMONIDES, Moshe. Mishneh Tora. Jerusalem: Mossad HaRav Kook, 1985.

PALESTINE BASIC LAW. Disponível em:

<https://www.constituteproject.org/constitution/Palestine_2005.pdf?lang=en>. Acesso em: 26 set. 2018.

TALMUDE BABILÔNICO. Jerusalem: Mesorah Publications, 2002.

VESHINANTAM. Disponível em:

<https://www.veshinantam.org.br/?subject=VESHINANTAM>. Acesso em: 10 nov. 2018.

YAGEL, Abraham. Sidur tehilat hashem com salmos traduzido e transliterado.

Rio de Janeiro: Editora Beith Lubavitch, 2014. p. 168-169. 